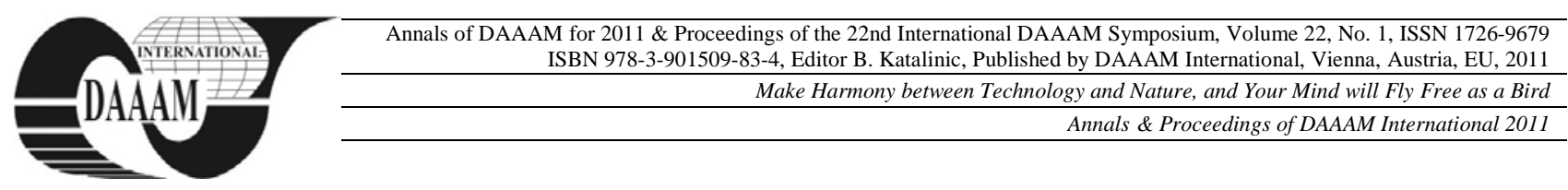

\title{
LOAN MANAGEMENT ACCOUNTING IN ROMANIAN BANKS
}

\author{
SOCOL, A[dela]
}

\begin{abstract}
This study presents the main technical management accounting aspects of loan loss provisioning phenomenon at the level of Romanian banks, which from 2009 have developed internal models fully compatible with IFRS. We describe the basic accounting aspects of the Romanian methodology for loan loss provision determining. The study outlines that the IFRS provision requirements influence the discretionary provisioning banking practices.
\end{abstract}

Key words: loan loss provisions, banking capital management, regulatory regime, IFRS

\section{INTRODUCTION}

Our purpose is to analyze the main benefits and challenges of new Romanian provisioning regulatory framework aligned with international standards IFRS - International Financial Reporting Standards. This article is organized in three parts. The first section links the accounting loan provisions information to banking management loan strategies, based on literature review. The second part provides an overview of loan loss provisions in Romania, according to the new implementing framework - IFRS. The last section concludes.

The research methodology is based on the description of the actual stage of knowledge in the area and direct documentation at the level of several Romanian banks and their accounting experiences in loan loss provisions LLP operations.

Banks' management is responsible for preparing and publishing financial statements in accordance with a national legal financial reporting framework. There are many users of the financial statements with different needs, such as shareholders, managers, financial market, supervisors, tax authorities, investors, customers, suppliers, employees and civil society. Banking financial accounting provides them regulatory requirement accounting reports, which contain information especially about bank's performance. In contrast, managerial accounting does not have followed any rules issued by standard-setting bodies and aims to provide information exclusively to managers and not available for the public. Bank's management needs accurate accounting information for decision making. Managerial accounting identifies measures, analyzes, interprets and communicates information to managers. Historically, management accounting in banking institutions was introduced considerable later in comparison with companies in other sectors, after ' $80 \mathrm{~s}$. The deep transformations of the banking system, and more specifically, deregulation, disintermediation and innovation processes contribute to develop of the banking management accounting (Carenys and Sales, 2008).

We choose the loan loss provisions (LLP) as the object of the study based our approach on their relevance for banks managers. In spite of the existence of the regulatory banking national environment in LLP domain, there are many aspects considered discretionary provisioning practices. It is recognized the role of the LLP in banks' profitability measurement and in this context, LLP become a major subject for management decisions. The modern provisioning regulatory framework aspires to International Financial Reporting Standards IFRS, which promote the true and fair value in banks' assets evaluation and an adequate methodology to measure the credit risk through the LLP.

A bank should have a system in place to reliably classify loans and should adopt a sound loan loss methodology, which addresses credit risk assessment policies, procedures and controls for assessing credit risk, identifying problem loans and determining LLP in a timely manner. A bank's aggregate amount of individual and collectively assessed LLP should be adequate to absorb estimated credit losses in the loan portfolio (Basel Committee for Banking Supervision, 2009).

Previous researchers studied the LLP especially in the following main management approaches: tools for banking capital management and for earnings or income-smoothing management. Also, the studies investigated whether bank managers use their discretion in estimating LLP to convey information about their banks' future prospects (Kanagaretnam and Yang, 2005; Soares de Pinho and Martins, 2009). Some authors investigated the determinants of income smoothing by management of LLP in bank around the word, and a possible discretionary component of the LLP mechanism at the level of the banking societies (Fonseca and Gonzales, 2008; Perez et al., 2006) or more conservative provisioning practices (example Asia) which may provide useful lessons (Angklomkliew et al., 2009). Dermine and Neto de Carvalho considered that a fair level of provisions on bad and doubtful loans is an essential input in mark-to-market accounting, and in the calculation of bank profitability, capital and solvency (Dermine and Neto de Carvalho, 2008). Papers that studied management accounting for loans approached especially the influence of the international accounting rules IFRS in the loan valuation process. Some authors studied the valuation of loan portfolios net of loan losses and showed that using a lower historic cost or economic value would provide the most relevant measure of loan value that may be measured with adequate reliability. (Benston and Wall, 2005). In Romania, studies on management accounting of LLP are relatively limited; the specialized papers prefer the descriptive or empirical approach of loan portfolio evolution in the banking industry. LLP are studied in the context of slender profit for 2009 and related to the objective of Romanian banks to maintain their viability on short and medium term (Nistor et al., 2010).

\section{LOAN LOSS PROVISIONS FRAMEWORK IN ROMANIA ON IFRS BASIS}

Banks have assets that can rapid change in value and whose value is often difficult to determine. For example, decrease in value of loans may have a significant effect on bank's solvency ratio and profitability. In the context of the recent subprime loans crisis, banks reacts and have to take a sharp pencil to nonperforming loans. In Romania, given the uncertainties induced by the global financial crisis, a worsening of banks' loan portfolios became manifest. Thus, the share of unadjusted 
exposure to loans and interests overdue for more than 90 days and/or for which legal proceedings were opened in total loans and interests widened to 7.9 percent at end-2009 from 2.8 percent at end-2008. The weak performance forced credit institutions to proceed to a significant increase in the provisions aimed at covering potential loan losses and to take a highly prudent approach to granting new loans. (National Bank of Romania, 2009).

Actually, Romanian banks apply IFRS for consolidated financial statements and at the individual level they apply European Directives. Although IFRS International Financial Reporting Standards do not become effective until 2012, the National Bank of Romania modified the primary banking legislation regarding to loan provisioning, in 2009. The regulation of LLP is made by National Bank of Romania, which establishes the legal requirements for measurement and reporting of the loan provisioning, according to IFRS and Basel II. With the coming into force of NBR Regulation No. 3 and 7/2009 and NBR Order No. 5/2009 on the classification of loans and provisions, as well as the establishment, regularization and use of specific risk provisions, credit institutions have begun implementing the provisions of the new regulation starting with the month when the Supervision Department of the NBR notified them of the decision on validating their in-house norms.

The credit-related exposures that lenders incur in their relationship with debtors from outside the credit institution sector fall into several categories, as follows: Standard S; Watch W; Substandard SS; Doubtful D; Loss L.

\begin{tabular}{|c|c|c|c|c|c|c|}
\hline \multirow[t]{2}{*}{ Debt Service: } & \multicolumn{5}{|c|}{$\begin{array}{l}\text { Category of Financial } \\
\text { Performance }\end{array}$} & \multirow{7}{*}{$\begin{array}{c}\text { Do not } \\
\text { start of } \\
\text { judicial } \\
\text { procedures } \\
\text { / Start of } \\
\text { judicial } \\
\text { procedures }\end{array}$} \\
\hline & "A" & "B" & "C" & "D" & "E" & \\
\hline & $\mathrm{S} / \mathrm{L}$ & $\mathrm{W} / \mathrm{L}$ & SS / L & $\mathrm{D} / \mathrm{L}$ & $\mathrm{L} / \mathrm{L}$ & \\
\hline $16-30$ & W/ L & $\mathrm{SS} / \mathrm{L}$ & $\mathrm{D} / \mathrm{L}$ & $\mathrm{L} / \mathrm{L}$ & $\mathrm{L} / \mathrm{L}$ & \\
\hline & $\mathrm{SS} / \mathrm{L}$ & $\mathrm{D} / \mathrm{L}$ & $\mathrm{L} / \mathrm{L}$ & $\mathrm{L} / \mathrm{L}$ & $\mathrm{L} / \mathrm{L}$ & \\
\hline 61-90 days & $\mathrm{D} / \mathrm{L}$ & $\mathrm{L} / \mathrm{L}$ & $\mathrm{L} / \mathrm{L}$ & $\mathrm{L} / \mathrm{L}$ & $\mathrm{L} / \mathrm{L}$ & \\
\hline Min. 91 days & $\mathrm{L} / \mathrm{L}$ & $\mathrm{L} / \mathrm{L}$ & $\mathrm{L} / \mathrm{L}$ & $\mathrm{L} / \mathrm{L}$ & $\mathrm{L} / \mathrm{L}$ & \\
\hline
\end{tabular}

Tab. 1. Loan Classification in Romanian Banking System

The credit institutions include the debtors outside the sector of credit institutions in financial performance categories which are marked from $\mathrm{A}$ to $\mathrm{E}$, in descending order of the quality thereof, according to the internal norms of the credit institutions, based on a score granted to quantitative and qualitative factors. The quantitative factors refer mainly to the following indicators, where they can be determined: liquidity, solvency, profitability, and risk, including exchange rate risk. Qualitative factors refer at least to the aspects related to the management of the analyzed entity, to the shareholding's quality, to the guarantees received, to the conditions of the market where the entity carries out its activity.

In order to establish the value whereby the amounts representing the credit-related exposure shall actually be reduced, the amounts posted in the accounting records, related to the eligible guarantees, shall be adjusted through the application of coefficients ranging between 0 and 1 , and the result shall be limited to the level of the guaranteed amounts.

\begin{tabular}{|l|c|c|}
\hline \multirow{2}{*}{ Loan Category } & \multicolumn{2}{|c|}{ Provision Coefficient } \\
\cline { 2 - 3 } & $\begin{array}{c}\text { For Loan in } \\
\text { Romanian Currency }\end{array}$ & $\begin{array}{c}\text { For Loan in } \\
\text { Foreign Currency }\end{array}$ \\
\hline Standard S & 0 & 0,07 \\
\hline Watch W & 0,05 & 0,08 \\
\hline Substandard SS & 0,2 & 0,23 \\
\hline Doubtful D & 0,5 & 0,53 \\
\hline Loss L & 1 & 1 \\
\hline
\end{tabular}

Tab. 2. LLP Coefficients in Romanian Banking System

\section{CONCLUSION}

The public presented purpose of the Romanian banking accounting requirements on IFRS basis is to ensure stakeholders that banks' assets are reflected at their fair and true value and that the provisions represent an adequate measure of credit risk. We consider that Romania offer an unusual example to test the LLP system, because we find proves of the combination between IFRS requirements and national specificity imposed by national legislation.

We identify a possible contradiction between the new IFRS LLP requirements and the national Bank of Romania influence (e.g. the internal LLP models of banks have to be validated by National Bank of Romania).

Otherwise, the actual national regulatory framework allow for more banks discretion in establishing the level of provisioning and more accurate treatment of than older Romanian Accounting Standard.

The future research in the area will focus on correlation between banks' provisions and the business cycle in the Romania's case, using bank level-information to study the prociclicality of LLP.

\section{REFERENCES}

Angklomkliew, S., George, J., Packer, F. (2009). Issues and Developments in Loan Loss Provisioning: the Case of Asia. BIS Quarterly Review, December, 69-83, ISSN 1683-013X

Benston, G.J., Wall, L.D. (2005). How should Banks Account for Loan Losses. Journal of Accounting and Public Policy, Vol. 24, 81-100, ISSN 0278-4254

Carenys, J., Sales, X. (2008). Costing the Banking Services: A Management Accounting Approach. Journal of Money, Investment and Banking, Issue 6, 34-53, ISSN 1450-288X

Dermine, J., Neto de Carvalho, C. (2008). Bank Loan-Loss Provisioning, Central Bank Rules vs. Estimation: The Case of Portugal. Journal of Financial Stability, Vol. 4, 1-22, ISSN 1572-3089

Fonseca, A.R., Gonzales F. (2008). Cross-country Determinants of Bank Income Smoothing by Managing Loan-Loss Provisions. Journal of Banking \& Finance, Vol. 32, 217228, ISSN 0378-4266

Kanagaretnam, K., Lobo, G.J., Yang D.H. (2005). Determinants of Signaling by Banks through Loan Loss Provision. Journal of Business Research, Vol. 58, 312-320, ISSN 0148-2963

Nistor, I., Pintea, M., Ulici, M. (2010). The Implications of Global Crisis on the Financial Performances of the Romanian Banking Systems. Scientific Annals of the "Alexandru Ioan Cuza" University of Iasi, Economic Sciences Section, Special Issue, 149-159, ISSN 2068-8717

Perez, D., Salas, V., Saurina, J. (2006). Earning and Capital Management in Alternative Loan Loss Provision Regulatory Regimes. Documentos de Trabajo Banco de Espana, No. 0614, 1-34, ISSN 1579-8666

Soares de Pinho, P., Martins, N.C. (2009). Determinants of Portuguese Bank's Provisioning Policies: Discretionary Behaviour of Generic and Specific Allowance. Journal of Money, Investment and Banking, Vol. 10, 43-56, ISSN 1450-288X

*** Basel Committee for Banking Supervision. (2009). Sound Credit Risk Assessment and Valuation for Loans, June, ISBN 92-9197-715-2

*** National Bank of Romania. (2009). Annual Report, ISSN 1453-3928

*** (2007) http://www.spi-romania.eu/program-2007/ifrs-loanloss-provisioning/ SPI Committee Meeting, Accessed on: 2010-12-20 